\title{
WEAVING IN A FOREIGN LAND: TRANSMISSION OF TEXTILE SKILLS THROUGH ENSLAVED WOMEN AND THROUGH INTERMARRIAGES IN THE ANCIENT EASTERN MEDITERRANEAN AND PONTUS
}

\begin{abstract}
In the ancient Eastern Mediterranean and beyond, textile production was a very dynamic activity where patterns of transmission of spinning and weaving skills through women can be traced over long distances. Even if it is traditionally believed that in antiquity lives of women were not so dynamic, several literary sources give consistent proofs of the mobility of women. For example, the "Iliad" is among the most important texts in providing instances of forced or willing migration of women highly skilled in the craft of weaving, e.g. Sidonian women brought by Paris to Troy for their craftsmanship, who made the most beautiful cloth from Hecuba's house (Hom. Il. 6.288-305), to Hector's vision of his wife, Andromache, carried as slave to Argos and forced to spin for her future mistress (Hom. Il. 6.454-456). The view from the archaeological and iconographic evidence is consistent with that drawn from the literary record. Thus, we can follow the literary sources supported by iconography and archaeology to identify patterns of transmission of textile crafts through women in an effort to gain a better understanding of the dynamics of textile production in the ancient Greek world.
\end{abstract}

Keywords: transmission of textile skills, cloth production, intermarriages, slavery

\section{Introduction}

In the ancient Mediterranean technologies and skills travelled over long distances. In the last decades scholars have been interested in understanding the mechanisms that stimulated the process of transmission of technologies, both in space and time during the prehistoric and ancient times. ${ }^{1}$ Meanwhile, new conclusions regarding the dynamics of various prehistoric and ancient crafts, be it metalwork or the development and circulation of pottery techniques and styles, have been drawn. ${ }^{2}$

\footnotetext{
* National Institute of Heritage of Romania and Faculty of History, University of Bucharest; (D) https://orcid.org/0000-00028664-8187; alina.ciobotaru@drd.unibuc.ro.

${ }^{1}$ For the impact of social interaction on conservation of material culture or changes of it see DeBoer 1990; for an introduction on learning and craft production see Minar and Crown 2001; with regard to social learning theory and the recent efforts to apply this new study field to the archaeological record see Eerkens and Lipo 2007; O'Brien 2008; Tehrani and Reide 2008; on the transmission of craft technologies and the modes of adoption of new techniques see Cutler 2012, 148-149; Menon 2014.

${ }^{2}$ For example, with regard to metal see: Forbes 1971; Morteani and Northover 1995; Yener 2000; Ottaway and Roberts 2008; White and Hamilton 2009; for pottery craft, techniques and styles see: Crown 2001; Herbich and Dietler 2008; Schauer 2008; Gauss et al. 2012; Vaessen 2014.
}

When it comes to textiles, we find ourselves in front of a special kind of craftsmanship. Since actual fabrics are extraordinarily rare finds in the archaeological record, it is very difficult for specialists to study ancient techniques of weaving, spinning and cloth-making. Archaeological discoveries related to this craft (mainly weaving and spinning implements, such as spindle whorls, loom weights, and spools) dominate the subject of various studies and articles, ${ }^{3}$ while new technologies used in archaeology gave scholars a possibility to investigate exceptional textiles though usually preserved in very poor conditions (e.g. mineralised on metal objects) $)^{4}$.

${ }^{3}$ On loom weights see, for example: Davidson and Thomson 1975; McLauchlin 1981; Barber 1991, 39-67; Mårtensson et al. 2009; Sofianou 2011; Sofroniew 2011; Gkika 2012; Sofianou 2012; Lassen 2015; Meo 2015; Olofsson and Nosch 2015; Tsakirgis 2016; Gleba 2017, 127-137. On spindle whorls see: Kemp and Vogelsang-Eastwood 2001, 265-306; Gleba 2008, 103-109; Mazăre 2012; Sauvage 2012; Vakirtzi 2012; Vakirtzi et al. 2014. For prehistoric and ancient spools see: Banks 1967; Coleman and Abramovitz 1986, 62-63,100-104; Gleba 2008, 140-150; Pavúk 2012; Siennicka 2012; Siennicka and Ulanowska 2016.

${ }^{4}$ For examples of textiles mineralised on metal and with regard to the methods and technologies used in order to study them see Spantidaki 2016, 106-143. 
Recently, Margarita Gleba investigated the textile cultures of Italy and Greece in the first half of the first millennium BC By using modern tools in the study of 192 textile fragments from Italy and 107 fragments from Greece, the author proved that "in contrast to the Iron Age textile culture of Italy, Iron Age Greece was more closely related to the Near Eastern, rather than Central European, tradition". The theory that at least until the beginning of the colonisation period Italy and Greece had totally different textile cultures which derived from their links either with Central Europe, or with the Near East, is a real gain for the domain. This is an example demonstrating that by employing modern tools for the analysis of ancient textile fragments, scholars are able today to point out theories and aspects which were not possible some decades ago. Thereby, much progress has been made recently regarding the study of archaeological textiles which gives us a possibility to approach the process of transmission of textile skills in antiquity in the Eastern Mediterranean and beyond.

In the present paper, I intend to highlight the importance of women as agents of transmission of textile skills through their roles as wives and slaves. The evidence discussed here comprises a representative selection of literary sources, including consistent examples from Homer, while the archaeological evidence from the Archaic and Classical periods will support my arguments. The quotation of ancient literary sources is very valuable as long as the material evidence is scarce and puzzling, but the facts and characters described by authors like Homer raise many methodological questions. ${ }^{5}$ The historical span of time covered by the "Iliad" and the "Odyssey" is highly debatable and the nature of the people described in their lyrics is questionable. These reasons made many scholars avoid using Homer as a historical source. ${ }^{6}$

Giving the fact that the Homeric epics contain a mixed image of old Bronze Age tradition and later Iron Age society, it is very difficult to assign facts described by Homer to any specific period. Around five centuries separated Homer's life from the last phase of the Bronze Age Palaces and due to recent developments in the study of ancient Greek language "the substantial differences between the world of Homer's epics and that of the Late Bronze Age have become clear, while the similarities with the Iron Age become more obvious"? Moreover, recent studies have proved that oral traditions were constantly reformulated in the context of contemporary societies ${ }^{8}$ and that "the epic tradition had been formed and shaped through successive very different social arrangements and material cultures". ${ }^{9}$ Consequently, some scholars

\footnotetext{
${ }^{5}$ Van Wees 1992, 1.

${ }^{6}$ Van Wees 1992, 1.

${ }^{7}$ Bennet 1997, 513 .

${ }^{8}$ Osborne 2004, 216: "oral traditions must always relate primarily to the world of those that hear them and that the material world of the poems aligns with that of eight-century Greece". On this matter see Morris 1986; Crielaard 1995; Crielaard 2002; Fowler 2004, 221.

${ }^{9}$ Osborne 2004, 206.
}

use the Homeric epics in order to reconstruct various aspects of social behaviour of the eight century and "as comparative evidence for social transformations from the Bronze Age to the later, historical periods". ${ }^{10}$

On the other hand, in the specific field of ancient textile production characters such as Penelope or Helen of Troy were often mentioned and they even made the subject of various papers. ${ }^{11}$ In my estimation, the female characters described in the Homeric epics could be regarded either as mythical figures or as ideal types of women (as in the case of the virtuous wife of Odysseus). Moreover, I consider that important suggestions regarding the women's mobility in the "Iliad" and "Odyssey", especially with regard to intermarriages and slavery in Early Archaic period, should be brought into discussion in the present paper focused on transmission of textile skills in ancient times.

The topic of technological practices and craft skills was broadly discussed and analysed in the literature. ${ }^{12}$ At the same time, the concept of "textile skills" was investigated by scholars interested in the ancient technologies of textile production. ${ }^{13}$ According to Joanne Cutler, "Individuals master craft knowledge and skills through the execution of progressively more difficult stages of the production sequence (which requires learning increasingly more difficult cognitive and motor-sensory skills), only moving on to the next stage once the previous stage has been mastered". ${ }^{14}$ In the same vein, Margarita Gleba states that the most important requirement for the transmission of skills is that the weaver should be able to "read the technology of transfer", while "technical expertise would require an extended period of apprenticeship under the supervision of a skilled craftsperson". ${ }^{15}$

Before I proceed to the main discussion, I would like to give a personal explanation of the concept "textile skills". Therefore, here the concept means technological knowledge of textile production crafts, including spinning, weaving, wool combing, clothes making and decorating, with the mention that each of this stages represents a skill by itself, and consequently ancient women can be designated "textile skilled" even if they master only one of the procedural sequences associated with garment production, for example spinning.

The transmission of textile skills is a process which does not necessarily include the transportation of textile tools from one region to another (see below the discussion related to slavery). However, when non-local textile tools are recorded in the archaeological inventory, they become a major

\footnotetext{
${ }^{10}$ Bennet 1997, 512.

${ }^{11}$ Reckford 1964; Lindsay 1974; Roisman 2006; Blondell 2009.

${ }^{12}$ Lemonier 1993; Hofman and Dobes 1999; Dobes 2000; Gosselain 2000; Long 2001, 72-101; Minar 2001.

${ }^{13}$ See Aronson 1989, 15; Hosfeld 2009, 46; Cutler 2012, $174-$ 175; Gleba 2017, 1219.

${ }^{14}$ Cutler 2012, 174. On the matter of craft knowledge apprenticeship see also Bril 2002, 142.

${ }^{15}$ Gleba 2014, 94-97.
} 
source for tracking women's movement in Antiquity. ${ }^{16}$ Moreover, the transfer of skills could be made in two manners: in space, between the members of the same generation, as a consequence of the mobility of craftspeople and products (known as horizontal transfer) or in time, from one generation to another (known as vertical transfer of skills). ${ }^{17}$ The present paper is focused especially on the first type.

\section{Slavery}

Slavery represented one of the most significant ways in which female mobility occurred in the ancient world. ${ }^{18}$ In the context of war, hand-skilled women were valuable goods to be taken as captives. Their skills in weaving and spinning would have been seen as important investments for the owner's oikos. Slaves were easy to transport from one region to another, much easier by comparison with herds, heavy furniture or other goods. They represented a category of 'booty' which could not be 'lost' on the way back home, while coins, jewellery, silver cups or other similar precious objects were liable to be lost or stolen much more easily. Transmission of textile skills through slave women has been pointed out recently by Joanne Cutler and Margarita Gleba. ${ }^{19}$

In terms of ancient household economy, female slave experts in textile production were very valuable because of their contribution to the household prosperity, though there are instances when female slaves were used in outdoor tasks such as agriculture..$^{20}$ Consequently, a female slave who did not know to handle the spindle and the loom was seen as a questionable investment. This fact is proved by Xenophon's account about Ichonomachus, who advised his young wife:

It is delightful to teach spinning to a maid who had no knowledge of it when you received her, and to double her worth to you: to take in hand a girl who is ignorant of housekeeping and service, and after teaching her and making her trustworthy and serviceable to find her worth any amount: to have the power of rewarding the discreet and useful members of your household, and of punishing anyone who turns out to be a rogue..1

Therefore, female slaves who had not mastered the craft of textile production were taught how to do it for economic reasons. On the other hand, techniques of cloth production which were specific for non-Greek populations could have

\footnotetext{
${ }^{16}$ See below the references regarding spindle whorls from Tell Sukas, a Levantine settlement located between Syria and Phoenicia, and wooden boxes containing textile tools from Scythian female burials of the $5^{\text {th }}$ and $4^{\text {th }}$ century BC.

${ }^{17}$ For a theoretical discussion on vertical and horizontal transmission of textile knowledge and skills see Aronson 1989, 15; Maynard et al. 1999, 386-387; Hosfeld 2009, 46; Cutler 2016, 174-175.

${ }^{18}$ Woolf 2013.

${ }^{19}$ Chadwick 1988; Cutler 2012, 147; Gleba 2014, 90; Cutler 2016.

${ }^{20}$ Fantham et al.1994, 109; Kosmopoulou 2001, 283.

${ }^{21}$ Xen. Oec. 7.41-43.
}

been performed in Greek poleis by foreign slaves. In this context, the mistress of the house or other local handmaids had a chance to be initiated by the women brought into the oikos from a distant land to new techniques unknown in their own polis or region.

For example, the most beautiful clothes from Hecuba's house were made by Phoenician women brought by Paris to Troy from Sidon, ${ }^{22}$ while in Eumaeus' childhood oikos lived a Phoenician slave woman who was "skilled in glorious handiwork" ( $\dot{\alpha} \gamma \lambda \alpha \grave{\alpha}$ है $\rho \gamma \alpha$ i $\delta v i ̃ \alpha) .{ }^{23}$ According to ancient sources, ${ }^{24}$ Phoenicians produced one of the most luxuriant and richly decorated garments in antiquity, and we can imagine how valuable Phoenician slave women would have been.

We can learn about the high value of slave women from the ancient literature, which is rich in accounts about women taken as slaves, and occasionally their handicraft is mentioned. The "Iliad" is one of the major literary sources on this matter. Achilles had slave women from the Dardanian city of Lyrnessus, ${ }^{25}$ from the Greek islands of Skyros, ${ }^{26}$ and Les$\operatorname{bos}^{27}$ and he expected to gain many others after the fall of Troy. ${ }^{28}$ During the Trojan War, Agamemnon promised to give Achilles seven women skilled in goodly handiwork, women of Lesbos, whom on the day when himself took well-built Lesbos I chose me from out the spoil, ${ }^{29}$ and thereby he fulfilled his promise by offering women skilled in goodly handiwork; seven they were, and the eighth was fair-cheeked Briseis..$^{30}$ Moreover, during the funerary games of Patroclus, Achilles offers a woman of manifold skill in handiwork, and they prized her at the worth of four oxen as a prize. ${ }^{31}$ This is a very precious account, as long as it mentions the exact value of the woman in question. And we should assume that it was easier to transport a highly skilled slave rather than four oxen.

That the enslaved women were expected to weave and spin for their masters is shown by some notable literary accounts. In the "Iliad", Agamemnon threatens Apollo's priest, Chryses, that his daughter will not be released. Instead, she will go to Argos as his slave, weaving for him and sleeping by his side. ${ }^{32}$ Moreover, Hector's biggest fear was represented by the vision of his wife taken as a slave and forced to weave for a cruel master. ${ }^{33}$

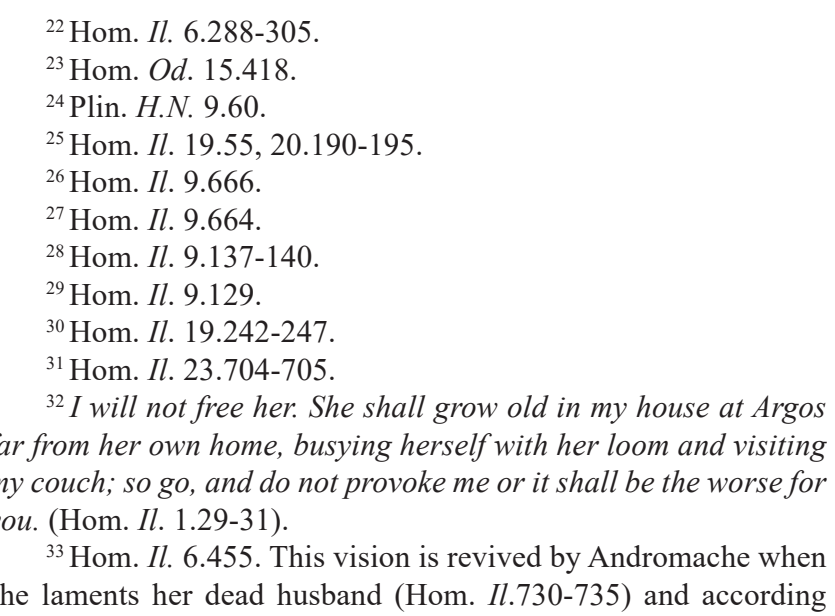


The Trojan women enslaved by the Achaeans after the fall of Troy in Euripides" "Hekuba" had a similar vision, asking their new masters whether they would be carried to the Dorian land, to Thessalian Phthia, to an island like Delos or to Athens, where they would weave the saffron peplos of Pallas Athena. ${ }^{34}$ This account offers an accurate image of the uncertainties brought by the new status of "slave". Consequently, there was a big difference between the status of the elite weavers and the position of slave women, as Andromake Karanika states referring to Andromache's activity of textile production:

Whereas what Andromache does as a Trojan elite confers honour on her, the same type of work done as a slave for another woman has a very different value. The sleve's work is done reluctantly and compulsorily and does not constitute an honorific duty in epic representation. ${ }^{35}$

It is probable that the enslaved women who mastered the craftsmanship of weaving and spinning were aware of their value and consequently they used their skills in order to gain a privileged position in their new home, having the chance to work together with their mistress. In ancient literature, the most important female figures, for example, Penelope, ${ }^{36}$ Andromache ${ }^{37}$ and Helen, ${ }^{38}$ are usually attended by their handmaids. Thereby, the image of the mistress who has the duty to supervise the handmaids while they perform domestic tasks and to work next to them is equally shown by the "Iliad" 39 and the "Odyssey". ${ }^{40}$ We can suppose that in special cases even a sort of friendship was born between the mistress and some of her handmaids, as we see in the case of Helen,

to other ancient sources, her premonitory speech became reality. Therefore, at the end of the war she became the concubine of Achilles' son, Neoptolemus, and afterwards, she was the slave of Helenus (see Dares Phrygius, De excidio Trojae 43), and eventually she married him becoming the queen of Epirus (Paus. 1.11). According to the same writer (Paus.), when Helenus died, Andromache travelled with their son, Pergamos, in the ancient city of Pergamon, where she finally died of old age. Andromache's fate is a true adventure which implies various statuses (slavery, marriage) and a migration over long distances (From Troy to Epirus, afterwards to Aeolis, and finally to Pergamon).

${ }^{34}$ Eur. Hec. 466. See as well the opposite vision of Iphigenia who used to lament that she would not be able anymore to weave at home, after she had been carried off in some special circumstances to the Black Sea Taurida, where she was the priest of Artemis: But now, as a stranger I live in an unfertile home on this sea that is hostile to strangers, without marriage, or children, or city, or friends, not raising hymns to Hera at Argos, nor weaving with my shuttle, in the singing loom, the likeness of Athenian Pallas and the Titans (Eur. IT. 219-224, translated by R. Potter, slightly modified).

${ }^{35}$ Karanika 2014, 81.

${ }^{36}$ Hom. Od. 19.513-514.

${ }^{37}$ Hom. Il. 6.490-500.

${ }^{38}$ Hom. Od. 4296-301.

${ }^{39}$ Hom. Il. 6.490-495.

${ }^{40}$ Hom. Od. 1.355-360. who used to have in Lacedaemon an old woolworker woman who was very dear to her. ${ }^{41}$

As a conclusion regarding the phenomenon of slavery and its role in transmission of textile skills in Ancient Mediterranean, I will hypothesise that slavery represented one of the principal forms of mobility for female textile production skills in antiquity. Thus, since the transport of textile tools by slave women was very difficult, if not impossible because of the crisis context in which these previously free women became slaves (wars, battles), it is very difficult to identify material traces of their presence in the archaeological record. However, as literary sources attest, many of them became agents of horizontal transmission of textile skills, by performing activities related to textile production specific in their homeland in their new establishments, as sometimes their skills were the only thing that they could take with them.

\section{(Inter)marriages}

The second pattern of transmission of textile skills to be discussed in this paper is represented by marriage, which sometimes implied female migration over very long distances. The Bible offers an excellent view of the wife's role as family's textile producer in Ancient Near East, ${ }^{42}$ while Xenophon quotes the duties of an ideal wife inside a Greek oikos, ${ }^{43}$ reflecting a similar image. In the Greek world, by marriage, a women could move from her father's oikos to her husband's oikos in the same polis, or she could travel from one polis to another, or even from a Greek city to a foreign land, possibly a barbarian one (for example, the Athenian princess Procne married the

${ }^{41}$ Hom. Il. 3.386-389.

${ }^{42} 10$. An excellent wife, who can find?

For her worth is far above jewels. [...]

13. She looks for wool and flax

And works with her hands in delight. [...]

19. She stretches out her hands to the distaff,

And her hands grasp the spindle. [...]

21. She is not afraid of the snow for her household,

For all her household are clothed with scarlet.

22. She makes coverings for herself;

Her clothing is fine linen and purple. [...] (Proverbs 31:10, $13,19,21,22)$.

${ }^{43}$ Cover is needed for the nursing of the infants; cover is needed for the making of the corn into bread, and likewise for the manufacture of clothes from the wool. And since both the indoor and the outdoor tasks demand labour and attention, God from the first adapted the woman's nature, I think, to the indoor and man's to the outdoor tasks and cares. (Xen. Oec. 7.21-23). Indeed you will, said I; "your duty will be to remain indoors and send out those servants whose work is outside, and superintend those who are to work indoors, and to receive the incomings, and distribute so much of them as must be spent, and watch over so much as is to be kept in store, and take care that the sum laid by for a year be not spent in a month. And when wool is brought to you, you must see that cloaks are made for those that want them. You must see too that the dry corn is in good condition for making food (Xen. Oec. 35-37). 
Thracian king Tereus and consequently followed him to his kingdom). ${ }^{44}$

There were only rare cases when the husband had to move into the polis of his wife: see the case of the Scythian king Scyles who married a Greek woman from Olbia and he lived with her in the Greek Pontic city. ${ }^{45}$ Moreover, when a barbarian woman became the wife of a Greek man, she was the one who was moving to his polis. Here it should be recounted that Hegesipyle, the daughter of the Thracian king Olores, lived in Athens as wife of the Greek general Miltiades. ${ }^{46}$ Rebeca Futo Kennedy remarked that many foreign women who used to live in Classical Athens were the wives of Athenian men. ${ }^{47}$ Outside the Greek world, the wife followed her husband to his city or region as well. Queen Hecuba, whose origins are highly debatable (Phrygia or maybe Thracia ${ }^{48}$ ), managed the oikos of King Priam of Troy before the fall of the city and her storerooms were full of luxuriant textiles. ${ }^{49}$

After the marriage, the new wife used her textile skills to produce clothes for her new family. ${ }^{50}$ This fact is associated with some of the most well-known ancient women: Penelope left Sparta to live in her husband's homeland, Ithaca, and years later she was weaving the funerary shroud of Laertes, waiting for Odysseus's return from the Trojan War; ${ }^{51}$ Andromache who was born in the Cilician Thebe, lived together with her husband in Troy, and during the time of the Trojan war weaving a web in the innermost part of the lofty house, a purple web of double fold, and therein was broidering flowers of varied hue; ${ }^{52}$ or Helen, born in Sparta and married there, afterwards spent a long period in Troy where she was weaving a great purple web of double fold.$^{53}$ After the fall of Troy, Telemachus found Helen back in Sparta, spinning with a gold distaff that she received, notably, from Alcandre, the wife of Polybus who dwelt in Thebes of Egypt. ${ }^{54}$

${ }^{44}$ When Philomela visited her sister in the Thracian land and she was abused by Tereus who cut out her tongue, she fastens her thread to a barbarian's loom, and weaves purple designs on a white background, revealing the crime. (Ov. Met. 6.571). Thereby, she was forced to use her textile skills achieved in Athens, even if the loom she used was a "barbarian" one (we do not have any insight whether this weaving installation was somehow different in comparison with the traditional warp-weighted loom used in Greece in the Classical period).

${ }^{45} \mathrm{Hdt}$. 4.76-80. See below a more detailed discussion on the active relationship between the Greek settlers in the Black Sea and the Scythians, with a case of study on the matter of textiles and costume reciprocal influences.

${ }^{46}$ Hdt. 6.39.1.

${ }^{47}$ Futo Kennedy 2014, 2.

${ }^{48}$ According to Homer, she was born in Phrygia, being the daughter of the king Dymas (Hom. Il. 16.715-716), while for Euripides (Hec. 3) and Vergil (Aen. 7.315 and Aen. 10.705) she had Thracian origins, being the daughter of the Thracian King Cisseus.

${ }^{49}$ Hom. Il. 6.285-290.

${ }^{50}$ See above notes 40 and 43 .

${ }^{51}$ Hom. Od. 2.93-106.

${ }^{52}$ Hom. Il. 22.437.

${ }^{53}$ Hom. Il. 3.125-128.

${ }^{54}$ Hom. Od. 4.129-131.
It is questionable whether all these women brought into the husband's house the textile tools that they used before the marriage, considering that a complete weaving installation, e.g. the warp-weighted loom was probably difficult to transport over long distances. ${ }^{55}$ Still, this hypothesis is supported by archaeological evidence: there are notable discoveries of non-local textile tools in the Mediterranean and Pontic region which could to be interpreted as clues for women's mobility in the Archaic ${ }^{56}$ and Classical period. ${ }^{57}$

We should recount here two spindle whorls discovered in Tell Sukas, a Levantine settlement located in Ğabla plain, between Syria and Phoenicia. The spindle whorls are dated to the sixth century BC. One of them is made from the sherd of a Greek vase, ${ }^{58}$ while the other is made from local clay, bearing an inscription of the Greek name Pesachore. ${ }^{59}$ As it is suggested by the inscription, the spindle whorls belonged to Greek women who produced textiles at a point of their lives in Tell Sukas. The status of these women remains for the moment an open question in the literature. While some scholars states that a Greek enoikismos existed at Tell Sukas starting in the Archaic period, ${ }^{60}$ others approached the nature of the Greek presence there more cautiously. ${ }^{61}$ No matter how puzzling the interpretation of the Greek pottery from Tell Sukas is, the presence of some Greek women who employed their skills in spinning and maybe weaving represents an interesting fact. ${ }^{62}$

More evidence comes from the Pontic area. Numerous wooden boxes containing textile tools were preserved in Scythian women burials from the $5^{\text {th }}$ and $4^{\text {th }}$ centuries BC in Southern Ukraine. ${ }^{63}$ Three of those exceptional discoveries have recently been investigated by Marina Daragan, Margarita Gleba, and Olga Buravchuk. ${ }^{64}$ Thus, the three wooden

\footnotetext{
${ }^{55}$ Giving the fact that wooden parts of ancient weaving installations are not preserved and they are missing from the archaeological inventory, archaeologists are able to identify the movements of textile technologies by analysing textile tools made of non-organic materials (e.g. clay loom-weights). We suppose that ancient brides who were skilled in the craft of textile production used to bring into their husband's house at least sets of loom weights, which were easier to carry. The emotional connection between ancient women and their textile tools has recently been pointed out by Quercia and Foxhall 2014, 63-82.

${ }^{56}$ Riis 1970 158; Jeffery 1990, 286, 288.

${ }^{57}$ Daragan et al. 2016.

${ }^{58}$ Ploug 1973, no. Cat. 425, pag. 90, Pl. XIX, Fig. G.

${ }^{59}$ Riis 1969, 444; Riis 1970,158, footnote 642, 174, Fig. 53D; Ploug 1973, no. cat. 424, pag. 90, P1. XIX, Fig. G.; Salskov Roberts 2015, 105-106, inventory no. TS5528.

${ }^{60}$ See Riis 1969, 449-450; Riis 1970, 129; Ploug 1973, 98-99; Haider 1996, 78.

${ }^{61}$ See Bonatz 1993, 132.

${ }^{62}$ For analogies see the pyramidal loom weight from Siris, Italy, which has a painted inscription with the Greek name Isodike. This loom weight is also dated to the sixth century BC (Jeffery 1961, 286,288 , P1. 54 with a bibliography). Regarding the Greek presence at Siris, it should be noted that a Kolophonian colony was settled here in the Archaic period.

${ }^{63}$ Daragan et al. 2016, 57.

${ }^{64}$ Daragan et al. 2016, 57.
} 
boxes of different sizes containing textile tools (tablets for weaving, distaffs, a spindle whorl made of a Greek amphora fragment, a wooden comb, an iron needle and textile yarn), ${ }^{65}$ preserved in a fragmentary state or in a complete form, were interpreted in the above-mentioned study as being of "Hellenic craftsmanship". These discoveries give insights into the technological transfers between the Scythian population and the Greek inhabitants who settled their colonies on the shores of Pontus Euxinos in the Archaic period. It is highly probable that these Classical Hellenic boxes and the textile tools preserved inside them were the material remains of textile technologies borrowed by the Scythians from the Greeks established in the vicinity. ${ }^{66}$ The presence of Hellenic boxes of textile tools in the barbarian graves from the north Pontic region could be interpreted as proof of individual mobility of women that may have encompassed intermarriages. Such a hypothesis is supported by the ancient authors who referred to the Greek Pontic cities in their works (as showed below).

Actual marriages between the Greek women from Histria in Dobruja or Olbia on the shore of the Southern Hypanis estuary (known today as the Bug River) and Scythians of high rank are attested by Herodotus. Ariapeites, the king of the Scythians in the first half of the $5^{\text {th }}$ century BC had three wives, including a Greek woman from Histria. Their son, Scyles, inherited the throne and he learned the Greek language and manners from his mother. This caused him to adopt the Greek Pontic costume and to marry a local woman. ${ }^{67}$

It is likely that while the Scythian population adopted Greek manners, costume and technologies of cloth production, the Pontic poleis borrowed textile culture from their barbarian neighbours. ${ }^{6}$ In this respect, I shall bring into the discussion the funerary stele of Leoxos, son of Molpagoras, which was unearthed in the necropolis of Olbia in 1895 and which is dated to $490 \mathrm{BC} .^{69}$ The stele, which is preserved in a fragmentary state, consists of two figural representations: on side A there is a young nude man (possibly deceased) next to his spear, while on the other side (side B) a figure seems to wear a rider costume of Scythian origin (trousers and a long-sleeved jerkin), facing left and carrying a bow. ${ }^{70}$ The clothed male could be interpreted in two ways: either he is Leoxos, or he is a Scythian. In the latter case, the representation becomes a mark of Leoxos' possible hinterland incursion during which he died. In any case, this funerary monument suggests once more permanent relations between the Greek Pontic cities and the local populations, including the exchange of textiles and textile technologies.

${ }^{65}$ The boxes were descovered in Kurgan 5 at Bulgakovo, in southern Ukraine.

${ }^{66}$ Daragan et al. 2016, 57.

${ }^{67}$ Hdt. 4.76-80.

${ }^{68}$ For an analytical discussion regarding the political, military and cultural links between the Greek colonies in the Lower Danube and the local populations see Irimia 2005; Skinner 2012.

${ }^{69}$ Boarman and Hammond 1982, 128.

${ }^{70}$ Skinner 2012, 172.
In later times, the fact that the people who lived in Olbia adopted barbarian costume for different reasons is strongly supported by the literary evidence. Dio Crysostomos provides an eloquent example, describing a young man from Olbia named Callistratus, who used to fight against the Scythians raids dressed as follows:

Suspended from his girdle he had a great cavalry sabre, and he was wearing trousers and all the rest of the Scythian costume and from his shoulders there hung a small black cape of thin material, as is usual with the people of Borysthenes. In fact, the rest of their apparel in general is regularly black, through the influence of a certain tribe of Scythians, the Blackcloaks, so named by the Greeks, doubtless for that very reason. ${ }^{71}$

According to Balbina Bäbler, the Greek inhabitants from the Pontic poleis borrowed the clothing style of the local populations in order to adapt to climate and, perhaps, the necessity of frequent riding. ${ }^{72}$ Whatever the reasons were, it is natural to assume that the permanent connections between the Greeks and the local people materialised in some occasions through intermarriages mainly for political and military purposes, brought technological exchanges, including costume, textile tools and textile skills transmission in both directions.

The archaeological evidence from the Mediterranean and Pontus is submitted to a variety of interpretations and it raises many questions. Can we fully accept that non-local textile tools are markers of female migration and therefore are the material evidence for transfer of textile skills through women? Moreover, can we be sure that these women travelled abroad especially for marriage? It has been argued that textile tools (as are for example the ordinary loom weights made of clay) do not retain an intrinsic value and therefore are unlikely to be traded. For this reason, they should have travelled only with their owners, who were almost always women. ${ }^{73}$ Joanne Cutler states that "Possible mechanisms for women migration within the Aegean and beyond include inter-marriage, migration as part of a family unit, raiding, slavery and the exchange of textile workers between the elites". ${ }^{74}$ Moreover, Margarita Gleba states that "Whether the mechanism of this mobility was intermarriage, migration or slavery is impossible to determine but the fact remains that textile equipment allows us to track women's movements, as well as the diffusion of textile technology and fashion". ${ }^{75}$

My personal remark is that while women usually did not engage in trade in the Ancient Mediterranean, slave women were probably forced many times to leave their textile tools behind when they were taken as slaves during a battle, and it is likely that the majority of non-local tools unearthed in

\footnotetext{
${ }^{71}$ D. Chr. Or. 36.7.

${ }^{72}$ Bälber 2002, 321.

${ }^{73}$ Barber 1991, 299; Cutler 2012, 175.

${ }^{74}$ Cutler 2016, 175.

${ }^{75}$ Gleba 2014, 90 .
} 
the Aegean and beyond in the Mediterranean and Pontus were carried by newly married women. Finally, not every non-local item related to household textile production could be exclusively interpreted as a mark of intermarriage, but this interpretation should be taken into account more often.

\section{Conclusions}

By combining ancient literary sources and archaeological evidence, I emphasised that slavery and intermarriage could be seen as pattern of transmission of textile skills in the ancient Mediterranean and beyond. Textile-skilled slave women were important investments in a Greek oikos. They produced valuable textiles for their masters by weaving and using cloth making techniques acquired in their homeland. Unfortunately, it is very difficult to trace material clues for female slaves in the archaeological record, as it is shown above. On the other hand, I argued that textile tools made of non-local clay or featuring non-local characteristics and local textile tools inscribed with foreign names could be interpreted as material proofs of intermarriage in antiquity. Regarding this matter, I brought into discussion archaeological evidence from Tell Sukas in Syria and from Scythian kurgans in nowadays Ukraine.
Hopefully, the topic of transmission of textile skills will be approached in the future in other papers by making a more complex analysis which would imply questions of commerce, war captives, and other modes of skills and technologies mobility. Moreover, studies of transmission of textile skills through other weaving techniques (for example tablet weaving ${ }^{76}$ which was a widespread technique, but its origins and modes of transmission are still uncertain), could be conducted in the future in order to draw new conclusions, and consequently to bring light on this puzzling topic.

\section{Acknowledgements}

I thank the organisers of the International Conference "Dynamics and Organisation of Textile Production in Past Societies in Europe and the Mediterranean" for giving me an opportunity to participate with a presentation. I also thank Agata Ulanowska, Małgorzata Siennicka and the anonymous reviewers for all helpful comments on the earlier drafts of this paper. Their reviews significantly improved the text. I would also like to warmly thank Terry Orr who helped me to correct the language errors.

Tablet weaving is a weaving method based on sets of tablets that allows the creations of narrow bands embellished with various patterns. The process of weaving is possible by making space to pass the weft through the warp (Meyers 2013, 258). This ancient method of weaving was widespread in Europe and Near East in antiquity, but its origins are supposed to be much earlier. Moreover, tablet weaving was largely used by the Etruscans (Gleba 2008, 138-139) and later by many European people, including the Vikings and Celtic tribes (Ræder Knudsen 1994). The origins of this technique are still debated in the literature and in the same situation are the mechanisms which allowed it to spread into such a large space. In my opinion, we still need more evidence in order to be able to identify the origins of tablet weaving. Nevertheless, a possibility that this technique originated in more than one place is highly possible. On the other hand, tablet weaving was a relative simple technique and the tools necessary in order to perform it (tablets for weaving made usually of wood and sometimes spools) were easy to carry. Consequently, this feature allowed that this method of weaving could spread on large areas in antiquity and in the Middle Ages. It is even possible that in ancient times newly married women carried into their new homes tablets for weaving rather than heavy and complex looms. Today, tablet weaving is practiced on a large scale. 


\section{Sources}

Anth. Gr. Anthologia Graeca, vol. 1. V. R. Platon (trans.). Londra, New York 1927.

Dares Phrygius De excidio Trojae - Dares The Trojan War: the Chronicles of Dictys of Crete, and Dares the Phrygian. R. M. Frazer (ed. and trans.). Indiana University Press 1966.

D. Chr. Dio Chrysostom. Orationes. J. de Arnim (trans.). Berlin 1893.

Eur. I.T Euripides. Iphigenia in Tauris. R. Potter (trans.). New York 1938.

Eur. Hec. $\quad$ Euripides, Hecuba. E. P. Coleridge (trans.). New York 1938.

Hdt.

Hom. Il.

Herodotus, Histories, 4 vols. A. D. Godley (trans.). Loeb Classical Library 1920.

Hom. Od. Homer, Iliad. 1 vol. A. T. Murray (trans.). Loeb Classical Library 1924.

Ov. Met.

Paus. Homer, Odyssey. A. T. Murray (trans.). Loeb Classical Library 1919.

Ovidius, Metamorphoses. A. Golding (trans.). London 1567.

Plin. H.N.

Proverbs Pausanias, Description of Greece. W. H. S. Jones, H.A. Omerod (trans.). Loeb Classical Library 1918.

Verg. Aen. $\quad$ Vergil, Aeneid. T. C. Williams (trans.). Boston 1910. Pliny the Elder, The Natural History. H. Rackham (trans.). Loeb Classical Library 1967.

Xen. Oec. $\quad$ Xenophon, Oeconomicus. E. C. Merchant, O. J. Todd (trans.). Loeb Classical Library 1997.

\section{Bibliography}

Aronson L. 1989. To Weave or Not to Weave. Apprenticeship Rules among the Akwete Igbo of Nigeria and the Baule of the Ivory Coast. In: M. W. Coy (ed.), Apprenticeship: From Theory to Method and Back Again. New York, 149-162.

Bälber B. 2012. Long-Haired Greeks in Trousers: Olbia and Dio Crysostomos (Or. 36, 'Borystheniticus'). "Ancient Civilisations" 8 (3-4), 311-327.

Banks E. C. 1967. The Early and Middle Helladic Small Objects from Lerna. PhD thesis, University of Cincinnati, University Microfilms.

Barber E. J. W. 1991. Prehistoric Textiles: The Development of Cloth in the Neolithic and Bronze Ages with Special Reference to the Aegean. Princeton.

Bennet J. 1997. Homer and the Bronze Age. In: I. Morris, B. Powell (eds.), A New Companion to Homer. Leiden, New York, Köln, 511-534.

Boardman J., Hammond N. G. L. 1982. The Cambridge Ancient History. The Expansion of the Greek World. Eight to Sixth Centuries BC, Second Edition. Cambridge.

Bonatz D. 1993. Some Considerations on the Material Culture of Coastal Syria in the Iron Age. "Egitto e Vicino Oriente" 16 , 123-157.

Blondell R. 2009. 'Third Cheerleader from the Left': from Homer's Helen to Helen of Troy. "Classical Receptions Journal” 1 (1), 4-22.

Bril B. 2002. L'apprentissage de gestes techniques: ordre de contraintes et variations culturelles. In: B. Bril, V. Roux (eds.), Le geste technique. Réflections méthodologiques et anthropologiques. Revue d’Anthropologie des Connaisances 14 (2), Ramonville Saint-Agne, 113-149.

Broudy E. 1979. The Book of Looms. A History of the Handloom from Ancient Times to the Present. Hanover, London.

Chadwick J. 1988. “The Women of Pylos”. In: J.-P. Olivier, T. G. Palaima (eds.), Texts, Tablets and Scribes. Studies in Mycenaean Epigraphy and Economy Offered to Emmet L. Bennett, Jr. Minos Supplement 10. Salamanca, 43-95.

Coleman J. E., Abramovitz K. 1986. Excavations at Pylos in Elis. Hesperia Supplement 21. Princeton, New Jersey.

Crielaard J. P. 1995. Homer, History and Archaeology: Some Remarks on the Date of the Homeric World. In: J. Crielaard (ed.), Homeric Questions: Essays in Philology, Ancient History and Archaeology, Including the Papers of a Conference Organized by the Netherlands Institute at Athens, 15 May 1993. Amsterdam, 201-288.

Crielaard J. P. 2002. Past or Present? Epic Poetry, Aristocratic Self-Representation and the Concept of Time in the Eighth and Seventh Centuries BC. In: F. Montanari, P. Ascheri (eds.), Omero tremila anni dopo. Rome, 239-295.

Crown P. L. 2001. Learning to Make Pottery in the Prehispanic American Southwest. "Journal of Anthropological Research" 57, 451-469.

Cutler J. 2012. Ariadne's Thread: The Adoption of Cretan Weaving Technology in the Wider Southern Aegean in the Mid-Second Millennium B.C. In: M.-L. Nosch, R. Laffineur (eds.), KOSMOS. Jewellery, Adornment and Textiles in the Aegean Bronze Age. Proceedings of the $13^{\text {th }}$ International Aegean Conference $/ 13^{e}$ Rencontre égéenne internationale, University of Copenhagen, Danish National Research Foundation's Centre for Textile Research, 21-26 April 2010. Aegaeum 33, Leuven, Liège, 145-154. 
Cutler J. 2016. Fashioning Identity: Weaving Technology, Dress and Cultural Change in the Middle and Bronze Age Southern Aegean. In: E. Gorogianni, P. Pavúk, L. Girella (eds.), Beyond Thalassocracies: Understanding Processes of Minoanisation and Mycenaeanisation in the Aegean. Oxford, Philadelphia, 172-185.

Daragan M., Gleba M., Buravchuk O. 2016. Pandora's Box: A Textile Tool Set from a Scythian Burial in Ukraine. In: C. Alfaro, J. Ortiz, L. Turell, M. Martinez (eds.), Textiles, Basketry and Dyes in the Ancient Mediterranean World. Proceedings of the Vth International Symposium on Textiles and Dyes in the Ancient Mediterranean World (Montserrat, 19-22 March, 2014). PURPUREAE VESTES V. Valencia, 57-61.

Davidson G. R., Thompson D. B. 1975. Small Objects from Pnyx 1. Amsterdam.

DeBoer W. R. 1990. Interaction, Imitation and Communication Expressed as Style: The Ucayili Experience. In: M. W. Conkey, C. A. Hastorf (eds.), The Use of Style in Archaeology. Cambridge, 82-104.

Eerkens J., Lipo C. 2007. Cultural Transmission Theory and the Archaeological Record: Providing Context to Understanding Variation and Temporal Changes in Material Culture. "Journal of Archaeological Research" 15, 239-274.

Fantham E., Foley H. P., Boymel Kampen N., Shapiro H. A. 1994. Women in the Classical World. Image and Text. Oxford.

Forbes R. J. 1971. Studies in Ancient Technologies VIII. Leiden.

Fowler R. 2004. The Homeric Question. In: R. Fowler (ed.), The Cambridge Companion to Homer. Cambridge, $220-234$.

Futo Kennedy R. 2014. Immigrant Women in Athens. Gender, Ethnicity, and Citizenship in the Classical City. New York, London.

Gauss W., Klebinder-Gauss G., von Rüden C. (eds.) 2012. The Transmission of Technical Knowledge in the Production of Ancient Mediterranean Pottery. Proceedings of the International Conference at the Austrian Archaeological Institute at Athens $23^{\text {rd }}-25^{\text {th }}$ November 2012. Vienna.

Gkika G. 2012. The Clay Loom Weights of Ancient Messene: Types, Decoration, Distribution. In: I. Tzachili, E. Zimi (eds.), Textiles and Dress in Greece and the Roman East: A Technological and Social Approach. Athens, 69-76.

Gleba M. 2008. Textile Production in Pre-Roman Italy. Ancient Textiles Series 4. Oxford.

Gleba M. 2014. Cloth Worth a King's Ransom: Textile Circulation and Transmission of Textile Craft in the Ancient Mediterranean. In: K. Rebay-Salisbury, A. Brysbaert, L. Foxhall (eds.), Knowledge Networks and Craft Traditions in the Ancient World. Material Crossovers. New York, 83-103.

Gleba M. 2017. Tracing Textile Cultures of Italy and Greece in the Early First Millennium BC. "Antiquity” 91 (359), $1205-1222$.

Gosselain O. P. 2000. Materialising Identities: An African Perspective. "Journal of Archaeological Method and Theory" 7 (3), 187-217.

Haider P. W. 1996. Griechen im Vorderen Orient und in Ägypten bis ca. 590 v. Chr. In: C. Ulf (ed.), Wege zur Genese griechischer Identität: Die Bedeutung der früharchaischen Zeit. Berlin, 59-115.

Herbich I., Dietler M. 2008. The Long Arm of the Mother-in-Law: Post-Marital Resocialization, Cultural Transmission and Material Style. In: M. Stark, B. Bowser, L. Horne (eds.), Cultural Transmission and Material Culture: Breaking Down Boundaries. Tucson, 223-244.

Hoffman C. R., Dobres M.-A. 1999. Conclusion: Making Material Culture, Making Culture Material. In: M.-A. Dobres, C. R. Hoffman (eds.), The Social Dynamics of Technology Practice, Politics and World Views. Washington, London, $209-222$.

Hosfeld R. 2009. Modes of Transmission and Material Culture Patterns in Craft Skills. In: S. Shennan (ed.), Pattern and Process in Cultural Evolution. Berkeley, 45-60.

Irimia M. 2005. Cu privire la raporturile dintre sciți, geți şi coloniile greceşti la Dunărea de Jos în secolele VI-IV a.Chr. "Revista română de studii eurasiatice" 1, 51-93.

Jeffery L. H. 1990. The Local Scripts of Archaic Greece. A Study of the Origin of the Greek Alphabet and its Development from the Eighth to the Fifth Centuries BC. (rev. ed. with supp. by A.W. Johnston). Oxford.

Karanika A. 2014. Voices at Work. Women, Performance, and Labor in Ancient Greece. Baltimore.

Kemp B. J., Vogelsang-Eastwood G. 2001. The Ancient Textile Industry at Amarna. Excavation Memoirs 68. London.

Kosmopoulou A. 2001. 'Working Women': Female Professionals on Classical Attic Gravestones. “The Annual of the British School at Athens" 96, 281-319.

Lassen A. W. 2015. Weaving with Crescent Shaped Loom Weights. In: E. Andersson Strand, M.-L. Nosch (eds.), Tools, Textiles and Contexts. Investigating Textile Production in the Aegean and Eastern Mediterranean Bronze Age. Ancient Textiles Series 21. Oxford, Philadelphia, 127-137.

Lemonnier P. (ed.) 1993. Technological Choices: Transformations in Material Cultures since the Neolithic. London. Lindsay J. 1974. Helen of Troy. London.

Mårtensson L., Nosch M.-L., Andersson Strand E. 2009. Shape of Things: Understanding a Loom Weight. "Oxford Journal of Archaeology" 28 (4), 373-398.

Maynard A. E., Greenfield P. M., Childs C. P. 1999. Culture, History, Biology and Body: Native and Non-Native Acquisition of Technological Skill. "Ethnos” 27 (3), 379-402. 
Mazăre P. 2012. Definirea și clasificarea artefactelor preistorice destinate torsului: Fusaiolele. "Terra Sebus. Acta Musei Sabesiensis" 4, 103-131.

McLauchlin B. K. 1981. New Evidence on the Mechanics of Loom Weights. "American Journal of Archaeology" 85 (1), $79-81$. Menon J. 2014. The Transmission of Craft Technologies in the Bronze Age. "Studies in People's History" 1 (2), $127-141$.

Meo F. 2015. L'attività tessile a Herakleia di Lucania tra i III e I secolo A.C. Roma.

Meyers G. 2013. Women and the Production of Ceremonial Textiles: A Reevaluation of Ceramic Textile Tools in Etrusco-Italic Sanctuaries. "American Journal of Archaeology” 117 (2), 247-274.

Minar C. J. 2001. Motor Skills and the Learning Process: The Conservation of Cordage Final Twist Directions in Communities of Practice. "Journal of Anthropological Research" 57 (4), 381-405.

Minar C. J., Crown P. L. 2001. Learning and Craft Production: An Introduction. "Journal of Anthropological Research” 57 (4), 369-380.

Morris I. 1986. The Use and Abuse of Homer. "Classical Antiquity” 5, 81-138.

Morteani G., Northover J. P. (eds.) 1995. Prehistoric Gold in Europe: Mines, Metallurgy and Manufacture. Dordrecht.

O’Brien M. J. (ed.) 2008. Cultural Transmission and Archaeology: Issues and Case Studies. Washington, D.C.

Olofsson L., Nosch M.-L. 2015. Test of Loom Weights and 2/2 Twill Weaving. In: E. Andersson Strand, M.-L. Nosch (eds.), Tools, Textiles and Contexts. Investigating Textile Production in the Aegean and Eastern Mediterranean Bronze Age. Ancient Textiles Series 21. Oxford, Philadelphia, 119-126.

Osborne R. 2004. Homer's Society. In: R. Fowler (ed.), The Cambridge Companion to Homer. Cambridge, 206-219.

Ottaway B. S., Roberts B. W. 2008. The Emergence of Metallurgy in Europe. In: A. Jones (ed.), Prehistoric Europe: Theory and Practice. Oxford, 193-225.

Pavúk P. 2012. Of Spools and Discoid Loom-Weights: Aegean-Type Weaving at Troy Revisited. In: M.-L. Nosch, R. Laffineur (eds.), KOSMOS. Jewellery, Adornment and Textiles in the Aegean Bronze Age. Proceedings of the $13^{\text {th }}$ International Aegean Conference / $13^{e}$ Rencontre égéenne internationale, University of Copenhagen, Danish National Research Foundation's Centre for Textile Research, 21-26 April 2010. Aegaeum 33. Leuven, Liège, 121-130.

Ploug G. 1973. Sūkās II. The Aegean, Corinthian and Eastern Greek Pottery and Terracottas. Copenhagen.

Quercia A., Foxhall L. 2014. Temporality, Materiality and Women's Networks: The Production and Manufacture of Loom Weights in the Greek and Indigenous Communities of Southern Italy. In: K. Rebay-Salisbury, A. Brysbaert, L. Foxhall (eds.), Knowledge Networks and Craft Traditions in the Ancient World. Material Crossovers. New York, 63-82.

Ræder Knudsen L. 1994. Analysis and Reconstruction of Two Tablet Woven Bands from the Celtic Burial Hochdorf. In: G. Jaacks, K. Tidow (eds.), North European Symposium for Archaeologial Textiles V, Neumünster, 53-60.

Reckford K. 1964. Helen in the Iliad. "Greek, Roman and Byzantine Studies" 5, 5-20.

Riis P. J. 1969. The First Greeks in Phoenicia and Their Settlement at Sūkās. In: C. F.-A. Schaeffer (ed.), Ugaritica. VI: publié à l'occasion de la XXXe campagne de fouilles à Ras Shamra (1968). Paris, 435-450.

Riis P. J. 1970. Sūkās I. The North-East Sanctuary and the First Settling of Greeks in Syria and Palestine. Copenhagen.

Roisman H. M. 2006. Helen in the Illiad. Causa Belli and Victim of War: From Silent Weaver to Public Speaker. "American Journal of Philology" 127 (1), 1-36.

Salskov Roberts H. 2015. Sūkās XI. The Attic Pottery and Commentary on the Greek Inscriptions found on Tall Sūkās. Copenhagen.

Sauvage C. 2013. Spinning from Old Threads: The Whorls from Ugarit at the Musée d'Archéologie Nationale (Saint-Germain-en-Laye) and at the Louvre. In: H. Koefoed, M.-L. Nosch, E. Anderson Strand (eds.), Textile Production and Consumption in the Ancient Near East. Archaeology, Epigraphy, Iconography. Ancient Textiles Series 12. Oxford, Oakville, 189-214.

Schauer P. M. 2008. Cultural Evolution in the Age of Athens: Drift and Selection in Greek-Figure Painted Pottery. Unpublished $\mathrm{PhD}$ thesis, University College London.

Siennicka M. 2012. Textile Production in Early Helladic Tiryns. In: M.-L. Nosch, R. Laffineur (eds.), KOSMOS. Jewellery, Adornment and Textiles in the Aegean Bronze Age. Proceedings of the $13^{\text {th }}$ International Aegean Conference $/ 13^{e}$ Rencontre égéenne internationale, University of Copenhagen, Danish National Research Foundation's Centre for Textile Research, 21-26 April 2010. Aegaeum 33. Leuven, Liège, 65-74.

Siennicka M., Ulanowska A. 2016. So Simple yet Universal. Contextual and Experimental Approach to Clay 'Spools'from Bronze Age Greece. In: J. Ortiz, C. Alfaro, L. Turell, M. J. Martinez (eds.), Textiles, Basketry and Dyes in the Ancient Mediterranean World. Proceedings of the $V^{\text {th }}$ International Symposium on Textiles and Dyes in the Ancient Mediterranean World (Montserrat, 19-22 March, 2014). PURPUREAE VESTES V. Valencia, 25-35.

Skinner J. 2012. The Invention of Greek Ethnography. From Homer to Herodotus. Oxford, New York.

Sofianou C. 2011. Loom Weights: Use and Manufacture at Trypitos, Siteia. In: K. T. Glowacki, N. Vogeikoff-Brogan (eds.), इTЕГА: The Archaeology of Houses and Households in Ancient Crete. Hesperia Supplement 44, 421-430. 
Sofroniew A. 2011. Women's Work: The Dedication of Loom Weights in the Sanctuaries of Southern Italy. "Pallas. The Gods of Small Things" 86, 191-209.

Spantidaki S. 2016. Textile Production in Classical Athens. Ancient Textiles Series 27. Oxford, Philadelphia.

Tehrani J. J., Reide F. 2008. Towards an Archaeology of Pedagogy: Learning, Teaching and the Generation of Material Culture Traditions. "World Archaeology" 40 (3), 1-26.

Tsakirgis B. 2016. Whole Cloth: Exploring the Question of Self-Sufficiency through the Evidence for Textile Manufacture and Purchase in Greek Houses. In: E. M. Harris, D. M. Lewis, M. Woolmer (eds.), The Ancient Greek Economy: Markets, Households and City-States. Cambridge, New York, 166-186.

Vaessen R. 2014. Craftsmanship at Athens in the 11 $1^{\text {th }}$ Century BCE: Improvisation, Networking and Pottery Making. In: K. Rebay-Salisbury, A. Brysbaert, L. Foxhall (eds.), Knowledge Networks and Craft Traditions in the Ancient World. Material Crossovers. New York, 127-146.

Vakirtzi S. 2012. The Decorated Spindle Whorls from Akrotiri, Thera. In: A. Papadopoulos, J. Kelder (eds.), Talanta. Proceedings of the Dutch Archaeological and Historical Society 44: Recent Research and Perspectives on the Late Bronze Age Eastern Mediterranean. 227-244.

Vakirtzi S., Koukouli-Chryssanthaki C., Papadopoulos S. 2014. Spindle Whorls from Two Prehistoric Settlements on Thassos, North Aegean. In: M. Harlow, C. Michel, M.-L. Nosch, (eds.), Prehistoric, Ancient Near Eastern and Aegean Textiles and Dress. An Interdisciplinary Anthology. Ancient Textiles Series 18. Oxford, Oakville, 43-57.

Van Wees H. 1992. War, Violence and Society in Homer and History. Amsterdam.

White J., Hamilton E. G. 2009. The Transmission of Early Bronze Technology to Thailand: New Perspectives. "Journal of World Prehistory" 22 (4), 357-397.

Woolf G. 2013. Female Mobility in the Roman West. In: E. Hemelrijk, G. Woolf (eds.), Women and the Roman City in the Latin West. Leiden, Boston, 351-368.

Yener K. A. 2000. The Domestication of Metals: The Rise of Complex Metal Industries in Anatolia. Leiden.

\section{Streszczenie}

\section{Tkanie na obczyźnie. Przekazywanie umiejętności rzemieślniczych poprzez niewolne kobiety i małżeństwa mieszane w starożytności, w basenie Morza Śródziemnego i Poncie}

W antyku, we wschodnim basenie Morza Śródziemnego produkcja włókiennicza rozwijała się intensywnie, a przekazywanie pomiędzy kobietami umiejętności przędzenia i tkania można prześledzić na rozległych obszarach. Nawet jeśli tradycyjny punkt widzenia sugeruje, że życie kobiet w antyku nie było szczególnie dynamiczne, to dowodów na ich migrację dostarczają źródła literackie. Jednym z nich jest „Iliada”, bogata w przykłady dobrowolnych lub przymusowych wędrówek kobiet, które posiadły wysokie umiejętności tkackie, jak np. kobiety z Sydonu, które przywiezione do Troi przez Parysa, wytwarzają najpiękniejsze tkaniny w domu Hekuby (Hom. Il. 6.288-305). Z kolei w wizji Hektora pojawia się jego żona Andromacha, która wywieziona jako niewolnica do Argos, zmuszona została do przędzenia dla swojej przyszłej pani (Hom. Il. 6.454-456). Obraz, jaki można uzyskać ze źródeł archeologicznych i ikonograficznych, wydaje się być spójny z obrazem literackim. Łącznie, różne rodzaje źródeł wskazują na mechanizmy przekazywania umiejętności włókienniczych pomiędzy kobietami i pozwalają na zrozumienie zmian w produkcji włókienniczej w świecie greckim. 
